\title{
Environmental Impacts Assessment of Chromium Minings in Bulqiza Area, Albania
}

Elizabeta Susaj

Enkelejda Kucaj

Erald Laçi

Department of Environment, Faculty of Urban Planning and Environment Management (FUPEM), University POLIS, Tirana, Albania

Lush Susaj

Department of Horticulture and Landscape Architecture, Faculty of Agriculture and Environment, Agricultural University of Tirana, Albania

\begin{abstract}
Bulqiza District is the largest chromium source, ranked fourth in the world for chrome reserves. It lays in the north-eastern part of Albania, 330-1800 m a.s.l, with $728 \mathrm{~km}^{2}$ area, between $41^{\circ} 30^{\prime} 43.1 \mathrm{~N}$ and 20014'56.21E. There are 136 entities with chromium extraction activity and around the city of Bulqiza $\left(2.6 \mathrm{~km}^{2}\right.$ and 13000 inhabitants), there are 33 entities. The aim of the study was the identification of the environmental state and environmental impact assessment of chromium extraction (chromite mining) and giving recommendations to minimize the negative effects of this activity. Field observations, questionnaires, chemical analysis of soil and water, meetings and interviews with central and local institutions as well as with residents were used for the realization of the study. The obtained results showed that chromium extraction causes numerous irreversible degradation of the environment in the Bulqiza area, such as the destruction of surface land layers and erosion, destruction of flora and fauna, soil and water pollution, health problems, unsustainable use and reduction of chromium reserves, etc. The inert waste that emerges after the chromium partition is discharged to the earth surface without any regularity, covering the surface of the soil and flora, leading to irreversible degradation of the environment. Most of the mining entities do not respect the contracts and environmental permit issued by the Ministry of Energy and Industry (MEI).
\end{abstract}

Keywords: Bulqiza, chromium, environmental impact assessment (EIA), environmental state.

\section{Introduction}

Albania is distinguished as a rich country for its mineral resources. Most of them have been discovered and exploited from ancient times up to date. Chrome, copper, iron-nickel and coal, are some of the minerals mined and treated in Albania. According to the MEI (2017), mining industry development in Albania has passed through three main stages: The first stage includes the period up to the end of World War II, marked by two important events. In 1922, has been compiled the first Geological Map of Albania, which was even the first of its kind in the Balkans. In 1929 has been approved the first Mining Law of the Albanian Kingdom, which paved the way to the exploration and/or exploitation of mineral resources in Albania; The second stage (1944-1994), marks the period when the mining activity has been organized in state-owned enterprises and the concept of mining privatization did not exist. The third stage includes the period 1994 up to date. It began the mining's privatization and licensing process, after the approval of Albanian Mining Law. Up to February $5^{\text {th }}$ 2016, there were issued 752 mining permits out of which were 673 exploitation permits, mostly in Bulqiza, Kruja, Berat, Tirana and Librazhdi districts. Out of 673 exploitation mining permits: 211 permits for chrome ore, from which, only in Bulqiza District there were issued 136 permits (MEI, 2017). The privatization process continued with the approval of the Law "On Concessions", and giving by concession of certain parts of mining industry (of this branch). The mining objects given in concession so far, are Bulqiza chromium mine and ferrochrome smelters of Burrel and Elbasan, chromium mines in Kalimash, Kalimashi dressing plant, etc (MEI, 2017). Albania is well known for its high potential in chromium ore, comparing to other Mediterranean and Balkans countries. The main chromium deposits are located in the Ophiolites of the Eastern Belt area, to Tropoja-KukësBulqiza-Shebenik-Pogradec direction. Bulqiza Ultrabasic Massif is the biggest chrome-potential massif, ranked fourth in the world for chrome reserves. This is a rare mine in its kind and has good quantitative and qualitative features $\left(\mathrm{Cr}_{2} \mathrm{O}_{3}\right.$ 
content $=40-42 \%)(\mathrm{MEI}, 2017)$. From the Bulqiza's mines, since 1948, over 15 million tons of chromium have been extracted and over 100,000 km of mining works have been carried out (Skarra, 2017). According to the National Natural Resources Authority (NNRA), in the depths of the largest mine in the country, the reserve chrome block amounts to 4 million tons (Open.data.al, 2014). According to Patel (2016), the mining effects is followed in general by significant environmental effects, as well as health effects on local population. Environmental effects include erosion, loss of biodiversity, air pollution, such as dust from blasting operation and haul roads (particular matters PM1 and PM2.5), NOx, $\mathrm{SOx}, \mathrm{CO}_{2}$ and $\mathrm{CO}_{\text {from }}$ heavy machinery using diesel, smoke from explosions, etj), pollution and contamination of soil, groundwater and surface water by chemicals used in mining process, etc. Underground mining is generally more hazardous for the people's health than surface mining because of poorer ventilation and visibility and the danger of rockfalls. The greatest risk arise from dust which may led to respiratory problems and from direct exposure. In the forest areas, mining may cause destruction and disturbance of ecosystems and habitats, and in areas of farming it may disturb productive grazing and croplands. In urbanised environments mining may produce noise pollution, dust pollution and visual pollution. Flooding of the surface (erosion), the collapse of the tunnels and the loss of land from the underground mining activity of coal, metals and other types of mining is a problem in most of the countries where the mining activity from the underground is concerned (Betournay, 2011), because it involves large-scale movements of waste rock and vegetation, similar to open pit mining. Environmental hazards are present during every step of the open-pit mining process. Hardrock mining exposes rock that has lain unexposed for geological eras. When crushed, these rocks expose radioactive elements, asbestos-like minerals, and metallic dust. During separation, residual rock slurries, which are mixtures of pulverized rock and liquid, are produced as tailings, toxic and radioactive elements from these liquids can leak into bedrock if not properly contained (Mission2016, 2016). According to MiningWatch Canada (2012), human exposure routes to dusts and particles PM10 and PM2.5 and chromium are breathing, swallowing, and skin contact. Chromium III and VI accumulate in animal and human tissues and their removal from the body is very slow. Observed toxic effects of chromium compounds in humans and animals include developmental issues, skin damage, respiratory, reproductive and digestive system injuries as well as skin cancer or internal organs. The ingestion of large amounts of hexavalent chromium compounds causes diarrhea, vomiting, stomach and intestinal ulceration, anemia, kidney and liver damage, abortion, coma and even death (MiningWatch Canada, 2012).

The aim of study was aim identification of the environmental situation and assessing the impact of the chrome mines and recommending alternatives in order to minimize the negative environmental impacts in the area.

\section{Material and methods}

The study was conducted during the period November 2016 - April 2017 in the area of Bulqiza. Quantitative and qualitative methods were used for the realization of the study. The quantitative method consisted in data collection for subjects/entities that perform the activity of chromium extraction in the Bulqiza area, demographic and socio-economic development data, as well as field evaluation of the environmental impacts as a result of the mining of chromium extraction activity. Collection of quantitative information and data was done through:

meetings, visits and interviews in central and local institutions

field surveys on the state of the environment in Bulqiza area, environmental impacts, causes, consequences and rehabilitation opportunities

water and soil chemical analysis

information from the internet

A questionnaire was drafted and field meetings and interviews were conducted with residents, environmental experts and entities performing their activity in the field of chromium extraction in the Bulqiza area, for their opinion on the effects of mining operations chromium extraction.

The qualitative method has consisted in the literature study on the environmental impacts of extractive mines in the environment (land degradation, land use, biodiversity, flora and fauna, water resources, development of inhabited centers, agricultural production, etc.), environmental impact assessment (EIA) at national and international level, the Albanian legislation in the field of chrome mining activities, environmental protection, biodiversity, etc. 


\section{Results and discussion}

\subsection{Entities with chromium exploitation mining activity in Bulqiza District and around the city}

According to the Ministry of Energy and Industry (MEI, 2017) and the Bulqiza Municipality (2017), in Bulqiza District there are 136 entities with chromium exploitation mining activity, and around the city of Bulqiza there are 33 entities, such as: AlbChrome Sh.p.k - a concessionaire company, Akev Sh.p.k, Gentari Sh.p.k, Mineral Invest Sh.p.k, Marej Sh.p.k, Isaku Sh.p.k, Klevi Bris Sh.p.k, Duriçi Sh.p.k, Ylberi Sh.p.k, Duriçi-07 Sh.p.k, Egi-K Sh.p.k, Drini Bulqiza Sh.p.k, etc (Table 1), as well as several anonimus entities with illegal activity, which use the natural chromium resources previously discovered.

Table 1. Some of entities with chromium exploitation mining activity around Bulqiza city (Register of Active Mining Licenses - Chromium - 05/02/2016) (MEl, 2017)

\begin{tabular}{|l|l|l|l|l|}
\hline Nr. & Nr of license & Date & Entity & District \\
\hline 1 & 677 & 16.09 .2002 & AlbChrome Sh.p.k & Bulqiza \\
\hline 2 & 869 & 17.06 .2005 & Arkev Sh.p.k & Bulqiza \\
\hline 3 & 934 & 13.04 .2006 & Gentari Sh.p.k & Bulqiza \\
\hline 4 & 1088 & 19.11 .2007 & Mineral Invest Sh.p.k & Bulqiza \\
\hline 5 & 1143 & 28.01 .2008 & Duriçi-07 Sh.p.k & Bulqiza \\
\hline 6 & 1155 & 03.03 .2008 & Egi-K Sh.p.k & Bulqiza \\
\hline 7 & $1163 / 1$ & 19.07 .2012 & Klevi Bris sh.p.k & Bulqiza \\
\hline 8 & 1197 & 01.07 .2008 & Duriçi Sh.p.k & Bulqiza \\
\hline 9 & $1271 / 1$ & 15.05 .2012 & Kadurtex Sh.p.k & Bulqiza \\
\hline 10 & 1279 & 17.12 .2008 & Gerda 07 Sh.p.k & Bulqiza \\
\hline 11 & 1281 & 17.12 .2008 & Gentari Sh.p.k & Bulqiza \\
\hline$\ldots$ & $\ldots$ & $\ldots$ & Etc. & ... \\
\hline
\end{tabular}

According to INSTAT (2017) and Bica (2015), at Bulqiza's mines there are employed a total of about 1000 employees (not all form Bulqiza but from other districts as well, such as Mat, Klos, Dibra, etc) of which about 600 are employed in AlbChrome Sh.p.k, with a monthly salary of about 60 thousand Albanian Lek (445 Euro) per month. This activity is the only employment opportunity for Bulqiza's young population. The use of chromium is done up to a depth of $250 \mathrm{~m}$ below sea level (level 21) (https://www.facebook.com/bulqizapasuriaeshqiperise/). From the interviews with city dwellers and with miners, it is said that the activity of chromium extraction did not enrich the city and Bulqiza area, but all Albania before the 1990 s, and only several private companies after 1990s.

\subsection{Demografic movements in the city of Bulqiza}

During the last 7 years (2010-2017), the population of Bulqiza declined by $6.11 \%$ (Municipality of Bulqiza, 2017; INSTAT (2011). The highest migration ocuured during 2011-2012 (Table 2). This may have been the result of population migration to the most developed areas of the country because of the lack of employment and services in their hometown.

Table 2. Demografic movements year by year in the city of Bulqiza, 2010-2017 (Bulqiza Municipality, 2017)

\begin{tabular}{|l|l|l|l|}
\hline \multirow{2}{*}{ Year } & \multirow{2}{*}{ Number of inhabitants } & Difference & \\
\cline { 3 - 4 } & & $\mathrm{Nr}$ & $\%$ \\
\hline 2010 & 13249 & 0 & 0 \\
\hline 2011 & 13480 & +231 & +1.74 \\
\hline 2012 & 12391 & -1089 & -8.079 \\
\hline 2013 & 12276 & -115 & -0.93 \\
\hline 2014 & 12323 & +47 & 0.38 \\
\hline 2015 & 12391 & +68 & 0.55 \\
\hline 2016 & 12388 & -3 & -0.024 \\
\hline 2017 & 12440 & +52 & 0.42 \\
\hline
\end{tabular}




\subsection{Identification of the negative environmental impacts of chromium exploitation mining activity}

In addition to the positive impact on the economy of Bulqiza's citizens and surrounding areas, the activity of extracting chromium ore in the Bulqiza area has been accompanied by significant negative impacts on the environment. Field surveys and data analysis of various institutions and environmental associations show that environmental problems are numerous such as air pollution, soil contamination, surfacewater and groundwater contamination, landscape degradation, destruction and disturbance of ecosystems and habitats (flora and fauna), land biodiversity loss, noise, vibrations, fear from earthquakes or the collapse of underground tunnels, unmanageable use of chromium resources and reserves, and health problems (respiratory disease, dizziness, vomiting, poisoning, stress, etc.), in some cases, the loss of the life of the miners.

\subsubsection{Contamination of the surface and ground waters}

The activity of exploiting chromium mines in the Bulqiza area has been accompanied by significant adverse impacts on the quality indicators of surfacewater and groundwater, as well as the contamination with chromium element as a result of excavation and excision of chrome ore inside the galleries, as well as the rinsing of mineral stocks in storage facilities and sterile wastes loaded with $\mathrm{Cr}$ dust at the depot. Field surveys and the results of the questionnaire conducted with residents of the city and surrounding areas indicate that in $70 \%$ of the cases, mining waters are not treated previously in decantation tubes, but are discharged into the open environment contaminating the groundwater and the soil. The water coming out of the mines using powerful pumps, is limestone water, rich in chromium, which is emitted to the environment uncontrollably and flows into surfacewater or infiltrates through rock fissures in groundwater (Table 3).

Table 3. Surface water parameters coming from one of the chromium mines operating in Bulqiza area (chemical analysis were performed at the Lab of Environment of Polis University and the Soil Lab of the ATTC Fushe Kruje)

\begin{tabular}{|l|l|l|l|l|l|l|}
\hline № & Indicators & Symbol & Unit & $\begin{array}{l}\text { Normal tap } \\
\text { water }\end{array}$ & $\begin{array}{l}\text { M1 (500 m from the } \\
\text { galery exit) }\end{array}$ & $\begin{array}{l}\text { M2 (1500 m from the } \\
\text { galery exit) }\end{array}$ \\
\hline 1 & Acidity & $\mathrm{pH}$ & $-\log \left[\mathrm{H}^{+}\right]$ & 7.2 & 9.58 & 8.91 \\
\hline 2 & Temperature & $\mathrm{t}$ & ${ }^{\circ} \mathrm{C}$ & 21.3 & 23.9 & 22.6 \\
\hline 3 & High range iron & $\mathrm{Fe}^{3+}$ & $\mathrm{mg} / \mathrm{l}$ & 0.0 & $0.43^{\text {** }}$ (very high) & $0.23^{*}$ (high) \\
\hline 4 & Free chlorine & $\mathrm{Cl}^{-}$ & $\mathrm{mg} / \mathrm{l}$ & 0.0 & 0.0 & 0.01 \\
\hline 5 & High range nitrogen & $\mathrm{NO}^{3-}$ & $\mathrm{mg} / \mathrm{l}$ & 0.0 & 0.04 & 0.27 \\
\hline 6 & Low range phosphate & $\mathrm{PO}_{4}^{3-}$ & $\mathrm{mg} / \mathrm{l}$ & 0.0 & 0.3 & $1.89^{* *}$ \\
\hline 7 & Sulphates & $\mathrm{PO}_{4}^{2-}$ & $\mathrm{mg} / \mathrm{l}$ & 0.0 & 0.0 & 0.2 \\
\hline 8 & Chromium (total) & $\mathrm{Cr}$ & $\mathrm{mg} / \mathrm{l}$ & 0.0 & $0.025^{* *}$ (very high) & $0.014^{*}\left(\mathrm{high}^{2-}\right.$ \\
\hline
\end{tabular}

These waters then end up in the surface waters of the city and eventually drain into the Drin River. Part of these groundwaters from natural sources can be used as drinking water for the city of Bulqiza and the surrounding areas and / or for irrigation of agricultural lands around the city, contaminationg the agricultural products as well (data not shown). In Albania, as in many other countries of the world, standards have been set and used, for the maximum content of $\mathrm{Cr}-\mathrm{VI}$ and Cr total of liquid discharges from mining activity (MiningWatch Canada, 2012; Law No. 10448, dated 14.07.2011, "On Environmental Permits", approximated, Law No. 60/2014, dated 19.06.2014, "On Amendments to Law No. 10448, dated 14.7.2011,"On Environmental Permits ", as amended, DCM no. 177, 31.03.2005, "On permissible liquid discharge rates and the criteria for zoning of receiving water environments" (CoM, 2005; MEI, 2017). These standards are set out in the usage permit, environmental permit and environmental statement, but their implementation leaves much to be desired, also considering the illegal activity of chromium extraction in the Bulqiza area.

\subsubsection{Air pollution and population and miners health problems}

Observations show that the activity of extracting chromium ore in the Bulqiza area is associated with indoor and the outdoor (atmosphere) air pollution around the mines from $\mathrm{CO}_{2}, \mathrm{CO}, \mathrm{SO}_{2}, \mathrm{H}_{2} \mathrm{~S}$, dust and particulate matter PM10 and PM2.5, which also contain chromium particles $(\mathrm{Cr})$ with different valences $(\mathrm{Cr}-\mathrm{I}$ to $\mathrm{Cr}-\mathrm{VI})$. Air pollution occurs as a result of excavations and explosions with explosives inside the mine that, in the absence of sufficient air ventilation, circulates through the galleries and comes out to the open air, from the circulation of heavy vehicles (trucks, wagons, freezers, etc) and loading 
and unloading of chrome ore and sterile waste. According to the Health Directorate of Bulqiza (2017), every year, there are about 50 new cases of respiratory disease, 15 new cases of untreated disease, 10 new cases with mental diseases, several accidents with the loss of organs (hands or feets), and 3-5 losses of life annually (not only from Bulqiza), without taking into consideration acute health problems such as skin injuries, diarrhea, vomiting, stomach and intestinal ulceration, anemia, etc.

\subsubsection{Erozion, soil degradation and contamination, degradation of the natural landscape}

Opening the new ways to reach new galleries and opening up new chromium careers has lead to the remove of the upper productive layer of soil (the main layer of physical, chemical and biological activity). As a result of surface interventions and in depth excavations for the extraction of chromium ore, soil deforestation and stripping of the soil surface has occurred, causing the phenomenon of erosion and the total soil degradation to appear massively. Improper disposal of the material (chrome ore and sterile - inert waste) to the storage squares around the mines and the galleries has led to the creation of "mountains" with mineral chromium stocks and sterile waste that have caused soil contamination and degradation and damage to the visual natural landscape (Figure 1). Disposal of inert materials and wastes, etc., have contributed to the pollution of soil and water (surface and ground water) and soil degradation, the destruction and loss of biodiversity, degradation of the environment, demolition, discontinuation, destruction of the natural ecosystems and damage to the visual landscape.
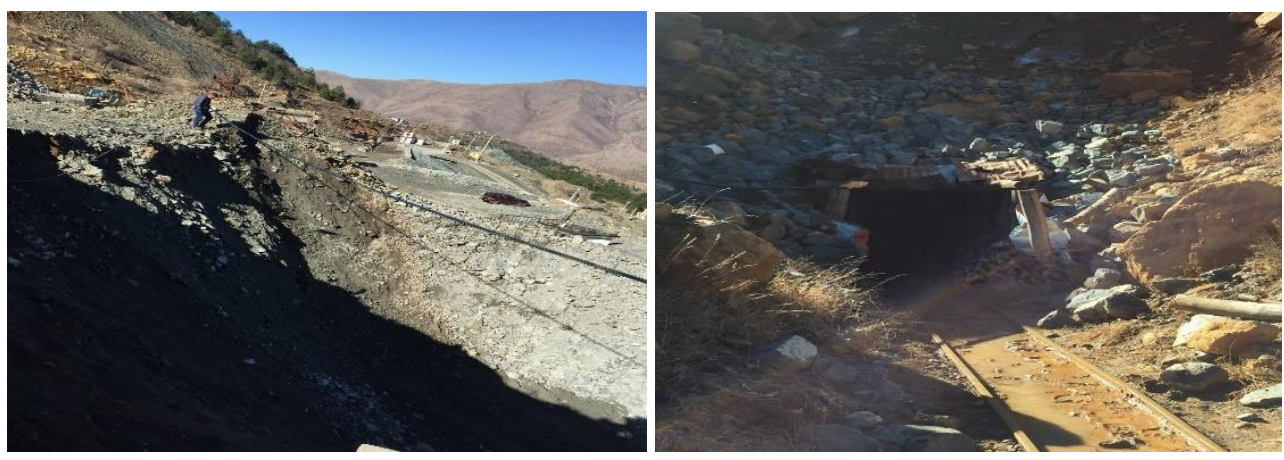

Figure 1. Erozion, soil degradation and contamination by the sterile waste of chromite mines (Photos by E. Laçi)

Soil chemical analysis, taken $500 \mathrm{~m}$ and $1500 \mathrm{~m}$ away form the mine's gallery showed that the total chromium content was very high (615 ppm $\mathrm{Cr}$ and $448 \mathrm{ppm} \mathrm{Cr}$ ) (Table 4), which means that in the case of plant cultivation for food for people or feed for animals, they will be poisoned for sure. There were also observed high levels of other heavy metals such as nickel (Ni) and cobalt (Co).

Table 4. Total Chromium content in the soil $500 \mathrm{~m}$ and $1500 \mathrm{~m}$ away from the gallery exit (Lab of the ATTC Fushe Kruje)

\begin{tabular}{|l|l|l|l|l|l|}
\hline № & Indicators & Symbol & Unit & $\begin{array}{l}\text { M1 }(500 \mathrm{~m} \text { from the } \\
\text { galery exit) }\end{array}$ & $\begin{array}{l}\text { M2 }(1500 \mathrm{~m} \text { from the } \\
\text { galery exit })\end{array}$ \\
\hline 1 & Acidity & $\mathrm{pH}$ & $-\log \left[\mathrm{H}^{+}\right]$ & 7.9 & 7.6 \\
\hline 2 & Electrical conductivity & $\mathrm{EC}$ & $\mathrm{MS} / \mathrm{cm}$ & 0.294 & 0.330 \\
\hline 3 & Chromium & $\mathrm{Cr}$ & $\mathrm{ppm}$ & 615 & 448 \\
\hline 4 & Nickel & $\mathrm{Ni}$ & $\mathrm{ppm}$ & 338 & 380 \\
\hline 5 & Cobalt & $\mathrm{Co}$ & $\mathrm{ppm}$ & 121 & 140 \\
\hline
\end{tabular}

\subsubsection{Acoustic pollution - noise, vibration and earthquake risk and land losses}

Around Bulqiza city, there are about 33 licensed and a number of unlicensed illegal subjects with exploitation and extraction of chromium ore activity. Field surveys and the results of the questionnaire conducted with residents (data not shown) indicate that heavy transport, loading and unloading machinery and mineral and sterile machinery - inert waste, cause continuous or periodic noise or vibrations in the town of Bulqiza, creating health problems For residents such as insomnia, 
stress and mental fatigue. The main mine, opened since 1948, today under the administration of Albchrome Sh.pk, is located very close to the town of Bulqiza, as a part of it. Mineral resources from this mine, with a 70 years activity, as well as other mines around the town of Bulqiza, have been exploited indefinitely, creating horizontal underground hollows, as well as many abandoned galleries. The development of the mine activity is already happening under the city, which is accompanied by fears of residents for the collapse and partial loss of land and the city in case of earthquakes, as it is known as an area with a very high seismic activity (Figure 2). The phenomenon has also led to the destruction and damage of wild flora and fauna, removed due to noise and vibrations, interruption of the natural landscape and destruction of their natural habitat.
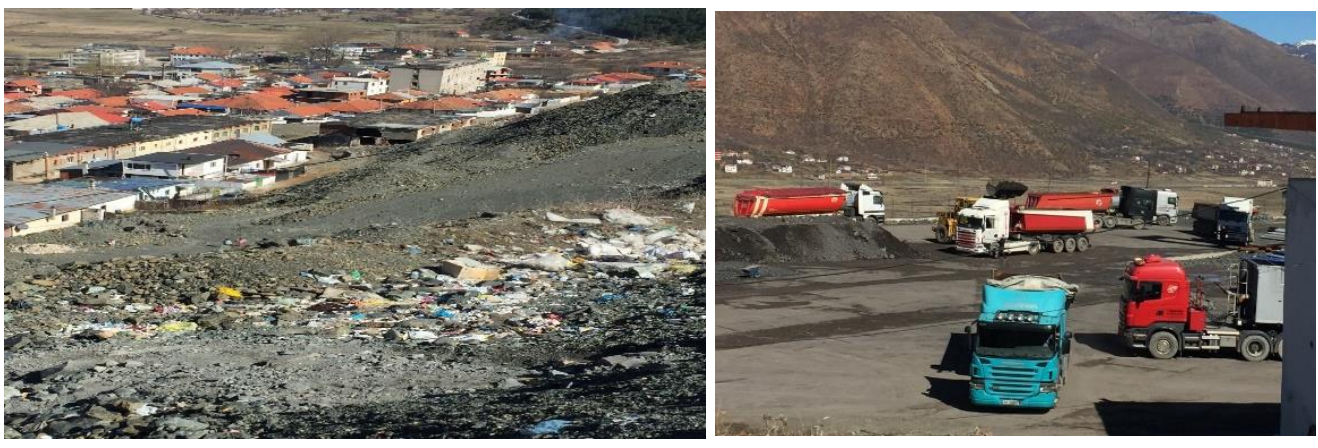

Figure 2. Soil and water pollution, and acoustic pollution by the move of heavy vehicles (Photos by E. Laçi)

\subsubsection{Reducing of the natural resources of chromium ore as a result of unmanageable use}

Particularly after 1990s, the activity of extracting and exploiting of chromium ore, benefiting form the long transition period, was done without any criteria, from licensed companies and unlicensed illegal companies. The main mine itself has passed in several hands (from DARFO, to ACR, to ALBCHROME - Balfin Group), where the use of chrome ore has been made based on existing stocks, only horizontally, without further study of the future. Extraction of the chrome ore from the bottom to the surface and the uncritical exploitation of these reserves has led to a critical reduction of the natural non-renewable resources of the chromium ore in Bulqiza area, compromising the sustainable development of the area, and the country as well, compromising the future generations to meet their needs. The Government institutions should be more rigorous on the law enforcing on environmental protection for our future.

\section{Conclusions and recommendations}

\subsection{Conclusions}

The area of Bulqiza is the area with the largest number of chrome extraction and exploition mines in Albania (136 subjects from 211 at the national level), where only around the city of Bulqiza there are 33 licensed and several unlicensed subjects. Chromium extraction and exploitation activity, in addition to the positive impact on employment and the economic growth and livelihoods of residents, is accompanied by numerous negative effects which, if not taken into account, will lead to total degradation of the natural environment in that area. The most important and most obvious negative impacts are air pollution, erosion, soil pollution and contamination, surfacewater and groundwater contamination, acoustic pollution (noise), vibrations and earthquakes, destruction and damage of flora and fauna, habitat interruption, loss of biodiversity, critical reduction of the natural non-renewable resources of the chromium ore, various health problems and loss of life of miners (the latter is most important).

\subsection{Recommendations}

All chromite mines must rigorously apply the rules of technical safety at work according to the legislation in force. The respective governmental institutions should immediately stop the illegal activity and all chromite mines will be provided with environmental permits and rigorously enforce the requirements of the law, regarding to the chrome minerals and inert waste. The Municipality of Bulqiza, in cooperation with relevant institutions in the Ministry of Energy and Industry (MEI) and the responsible environmental institutions (National Environmental Agency and Regional Environmental Agency), should 
be more cautious in addressing the environmental aspects and in the implementation of all specified conditions on environmental permits for the extraction and exploition of chromium mineral resources. For chrome mining activity in the area, must be developed a strategic environmental plan with a detailed cost-benefit analysis considering the environmental costs in the long-term, considering the concept and the reality of sustainable development in the use of non-renewable natural resources / reserves, chromium in this case. Respective governmental institutions should immediately take measures for the rehabilitation of the landscape, adapting for other purposes, objects that are out of function and have a negative visual effect in the area. People need to be aware that what the nature has given to us belong to the next generations.

\section{References}

[1] Betournay, M. C. (2011, April 7). Underground Mining and Its Surface Effects. Retrieved http://www.fhwa.dot.gov/engineering/geotech/hazards/mine/workshops/iawkshp/betourna2.cfm

[2] Bica, D. (2015/07/12). Environmental impacts coming form the mines activity in Bulqiza (In Albanian: Ndikimet mjedisore që vijnë nga aktiviteti minerar në Bulqizë. https://alb-info.com/2015/07/12/idete-dhe-strategjite-perpermiresimin-e-situates-mjedisore-qe-vijne-nga-aktiviteti-minerar-ne-bulqize/

[3] Council of Ministers (CoM) (2005). Decision of the Council of Ministers Nr. 177, dated 31.03.2055, "On permissible liquid discharge rates and the criteria for zoning of receiving water environments" (In Albanian: KM (Këshilli i Ministrave). (2005). VKM Nr. 177, 31.03.2005, "Për normat e lejuara të shkarkimeve të lëngëta dhe kriteret e zonimit të mjediseve ujore pritëse"). The Official Notebook of the Republic of Albania Nr. 24, 18 April 2005. http://www.qbz.gov.al/botime/fletore_zyrtare/2005/PDF-2005/24-2005.pdf

[4] Health Directorate of Bulqiza. (2017). Health data on the Municipality of Bulqiza through years. Oral (personal communication) (unpublished data).

[5] NSTAT (2017). Labour Market. http://www.instat.gov.al/al/themes/tregu-i-pun\%C3\%ABs.aspx.

[6] INSTAT (2011). Census-AL 2011. http://www.instat.gov.al/al/census/census-2011/t\%C3\%AB- dh\%C3\%ABnat-ecensus-2011.aspx

[7] MEI (Ministry of Energy and industry). (2017/04/20). Invest in Albanian Natural Resources! Mineral Resources in Albania. http://www.energjia.gov.al/files/userfiles/Strategjike/Broshura_Minierat.pdf

[8] MiningWatch Canada. (2012). Potential Toxic Effects of Chromium, Chromite Mining and Ferrochrome Production: A Literature Review. 56 p: i-x, 6-21.39-43.http://miningwatch.ca/sites/default/files/chromite_review.pdf

[9] Mission2016. (2016). The future of strategic Resources. Environmental Risks of Mining. http://web.mit.edu/12.000/www/m2016/finalwebsite/problems/mining.html (Assessed 17 April, 2017).

[10] Municipality of Bulqiza. (2017). Data on the socio-economic development of the municipality of Bulqiza through years. Personal communication. (unpublished data).

[11] Patel, S. (2016). Impact of mining on environment.

[12] http://www.authorstream.com/Presentation/suvampatel-2079326- impact-mining-environment/

[13] Skarra, K. (15 February, 2017). Bulqiza's chrome has conquered world markets. (In Albanian: Kromi i Bulqizës ka pushtuar tregjet e botës). http:/www.gazetabulqiza.al/?p=1845 https://www.facebook.com/bulqizapasuriaeshqiperise/ 